\title{
Serum Immunoglobulins level in Bangladeshi Dockyard Labourers
}

\author{
Muhammad Shahdaat Bin Sayeed ${ }^{1}$, Abdullah Al Maruf ${ }^{2}$, Amitouzea Basher $^{3}$, \\ Naimul Huda ${ }^{3}$, Syeda Amina Toufique ${ }^{3}$ and Abul Hasnat ${ }^{2}$ \\ ${ }^{1}$ Faculty of Pharmacy, University of Dhaka, Dhaka-1000, Bangladesh. \\ ${ }^{2}$ Department of Clinical Pharmacy and Pharmacology, University of Dhaka, Dhaka-1000, Bangladesh. \\ ${ }^{3}$ Department of Pharmacy, University of Asia Pacific, Dhanmondi, Dhaka-1209, Bangladesh.
}

\begin{abstract}
The purpose of the study was to evaluate the serum level of immunoglobulins in Bangladeshi dockyard labourers compared to healthy day labourers. One hundred dockyard labourers, age ranging from 19 to 42 years, were randomly recruited from different dockyards of Keranigonj, Dhaka, Bangladesh. The control group included 100 day labourers matched by age, sex and socio-economic status to that of dockyard labourers who were not exposed to environmental hazards of dockyard. Blood samples were analyzed for determining the serum levels of immunoglobulin ( $\operatorname{IgG}, \operatorname{IgA} \& \operatorname{IgM})$ by turbidimetry method using an immunoglobulin kit. The serum concentration of IgA \& IgG were found to be decreased, whereas that of IgM increased in dockyard labourers as compared to control group, but the differences were not significant $(p>0.05)$. No significant relationship was found between the socio-demographic variables and immunoglobulin levels at $5 \%$ level of significance. But study with larger number of population is required for further evaluation of the relationship between the immune status and health hazards to confirm these findings.
\end{abstract}

Key words: Dockyard labourers; Occupational exposure; Immunoglobulin.

\section{INTRODUCTION}

Dockyard is an area with docks and workshops for building, breaking, outfitting and repairing of ships, launches, boats and other vessels. Both ship breaking \& ship building are challenging process, due to the structural complexity of ships and involvement of many of the environmental, safety, and health related issues. ${ }^{1}$ Bangladesh alone breaks 50 percent of the ships, which are scraped in the world every year. As a result, it is now known worldwide as one of the major ship breaking countries. At present, there are more than 24 ship breaking yards in Bangladesh. ${ }^{2}$ Every year $60-65$

Correspondence to:

Abul Hasnat

Tel: +880-2-9661920-73 Extn. 8164; Fax: +880-2-8615583

E-mail: ahasnat99@yahoo.com

Dhaka Univ. J. Pharm. Sci. 9(2): 91-95, 2010 (December) ships are either being dismantled or awaiting dismantling process. ${ }^{3}$ Ship breaking activities include a series of risky tasks which pose threats to the environment and working people. Depending on their size and function, scrapped ships have an unladed weight of between 5,000 and 40,000 tones, $95 \%$ of which is steel, coated with paints containing lead, cadmium, organotins, arsenic, zinc and chromium. ${ }^{4}$ Ships also contain a wide range of hazardous wastes like sealants containing polychlorinated biphenyl compounds, various types of asbestos, etc. ${ }^{4}$ The main causes of health hazards in dockyard labourers are continuous menial work, direct exposure to heavy metals, welding fumes, and unhealthy condition. Therefore, the workers suffer a number of diseases. The general symptoms of disease in labourers are muscle pain, breathing difficulty, gastric problems, and skin diseases. ${ }^{4}$ Due to continuous exposure to 
toxic substances and stressful conditions prevailing in a dockyard, it is likely that the serum levels of immunoglobulin may be altered which may be one of the reasons for various diseases in the dockyard labourers. ${ }^{4}$

As no work has been reported regarding immune status of dockyard labourers, the present study was designed to investigate the serum level of immunoglobulins (IgA, IgG, and $\operatorname{IgM}$ ) of dockyard labourers and compare the result with that of control group who are not exposed to the hazards of dockyard. The correlation between immunoglobulin levels in dockyard labourers with their different socio-demographic factors was also investigated in the study.

\section{MATERIALS AND METHODS}

Subject selection. One hundred dockyard labourers, age ranging from 19 to 42 years, were randomly recruited from different dockyards of Keranigonj, Dhaka, Bangladesh during the period of January to December, 2009. The control group included 100 healthy day labourers matched by age, sex and socio-economic status to that of the dockyard labourers, with no previous history of any psychiatric disorders or any medical disease that can affect the immune system. Both groups were interviewed and asked to complete a questionnaire concerning their use of drugs, including use of any anti-diabetic medication or steroids, smoking or other habits that could affect the outcome of the results. Investigators helped the subjects to fill up the form who had no formal education. Both groups were categorized in terms of their socio-economic status. Study protocol and volunteer's consent form were approved by Bangladesh Medical Research Council (BMRC).

A routine physical check up was done to check their body weight, nutritional condition, and blood pressure. All study subjects were evaluated clinically (history and clinical examination). Laboratory investigations including 1) Complete blood count: to exclude subjects with anaemia, leucopenia, leucocytosis, eosinophilia or any other abnormal figures in blood count, 2) Thyroid function tests: to exclude subjects with high or low serum $T_{3}$ and $T_{4}$ levels, 3) Renal function tests (serum creatinine and creatinine clearance): to exclude subjects with renal impairment, 4) Liver function tests: to exclude subjects with liver insufficiency, especially those with high liver enzymes or those with diminished albumin level or high globulin level, 5) Urine and stool analysis : to exclude subjects with urinary tract infection or parasitic infestations, were carried out. Exclusion criteria included subjects with previous diseases that can affect immunity, e.g. rheumatic fever, rheumatoid arthritis, liver diseases \& renal diseases, etc.

Blood sample collection. Ten $\mathrm{ml}$ of venous blood was collected from each of the dockyard labourers and control subjects. Blood samples were allowed to clot for half an hour and then centrifuged at $5000 \mathrm{rpm}$ for 15 minutes. The clear supernatant was collected by micropipette \& stored in precleaned metal-free polypropylene tubes to preserve at $-80^{\circ} \mathrm{C}$ until further analysis. ${ }^{5-7}$

Determination of serum immunoglobulin. The serum immunoglobulin (IgG, $\operatorname{IgA}$, and $\operatorname{IgM}$ ) levels in both dockyard labourers and controls were determined by turbidimetry method using an immunoglobulin kit (Chronolab, Switzerland). The experiments were carried out in the Department of Clinical Pharmacy \& Pharmacology, University of Dhaka, Bangladesh. In this method, anti-human antibodies were mixed with samples containing IgG, $\operatorname{IgA}$, and IgM that formed insoluble antigen-antibody complexes. These complexes caused an absorbance change depending upon the immunoglobulin concentration that was quantified by a calibrator. Calculation was done with the help of calibration curves for each immunoglobulin. ${ }^{5-7}$ Calibration standards of different immunoglobulins were prepared by diluting the reference standards with normal saline to get the desired concentration ranges (40-800 $\mathrm{mg} / \mathrm{dL}$ for IgG, $6-144 \mathrm{mg} / \mathrm{dL}$ for $\mathrm{IgA}$ and $4-80 \mathrm{mg} / \mathrm{dL}$ for $\operatorname{IgM}) .5 \mu \mathrm{L}$ of all the calibrator standards were pipetted into pre-marked wells of each of the microtitre plate. Similarly the $5 \mu \mathrm{L}$ of diluted serum (1:10 with normal saline) samples were 
also pipetted into respective wells of microtitre plates. $500 \mu \mathrm{L}$ of Quantia immunoglobulin activation buffer was added to these and incubated for 5 minutes and the absorbance (A1) was taken. Antihuman immunoglobulins (Anti IgG, Anti IgA and Anti $\operatorname{IgM})(50 \mu \mathrm{L}$ of each) were added to the wells of their respective microtitre plates. The plates were incubated for 5 minutes to react the antihuman immunoglobulins with the test serum and calibrator protein. Absorbance (A2) was taken at $550 \mathrm{~nm}$ for $\operatorname{IgG}$ and $\operatorname{IgA}$ and at $405 \mathrm{~nm}$ for IgM after proper mixing. Difference between the two absorbances $(\Delta \mathrm{A}=\mathrm{A} 2$ - $\mathrm{A} 1)$ was used for calculation. The concentration of immunoglobulins was calculated against the calibration curves of each individual immunoglobulin.

Statistical analysis. The SPSS software package (Version 14.0, SPSS Inc., Chicago, Illinois, USA) was used to analyze the data. Descriptive statistics were used for all variables. Values were expressed as percentage, mean, and standard deviation. To assess distribution pattern for case and control, one sample kolmogorov-smirnov test was done. Chi-square test was performed to compare the socio-demographic data between dockyard labourers and control group. Linear regression analysis and independent $t$-test were also performed to determine the extent of contribution of socio-demographic factors and BMI on the level of trace elements and immunoglobulin. All comparisons were 2-tailed, and $p$ values of $<0.05$ were considered significant.

\section{RESULTS AND DISCUSSION}

Socio-demographic data of dockyard labourers $(n=100)$ and control subjects $(n=100)$ have been shown in Table 1. These data revealed that the means of BMI were $19.683 \pm 2.378 \mathrm{Kg} / \mathrm{m}^{2}$ and $20.742 \pm$ $2.504 \mathrm{Kg} / \mathrm{m}^{2}$ for dockyard labourers and control group respectively. The education level of most of the dockyard labourers was below Secondary and most of them had very poor income having an average monthly income of USD $62.63 \pm 22.23$. Most of the labourers were young (52\% was in the age range of 19 to 24 years) and from semi-urban area
(56\%). Majority of the labourers had a habit of smoking (68\%). No significant difference was obtained for socio-demographic factors between dockyard labourers and control group $(p>0.05)$.

The serum immunoglobulin ( $\operatorname{IgG}, \operatorname{IgA} \& \operatorname{IgM}$ ) concentrations were determined and compared to control subjects (Table 2). In this study, it was found that the serum concentrations of $\operatorname{IgG}$ and $\operatorname{IgA}$ were lower, whereas serum IgM was higher in dockyard labourers compared to control group (Table 2), but the differences were not statistically significant $(p>0.05)$.

For regression analysis, we considered the serum levels of $\operatorname{IgG}, \operatorname{IgM} \& \operatorname{IgA}$ as dependant variable \& socio-demographic factors including age, BMI, income, occupation, education, residence and smoking habit as independent variable. No significant relationship between these variables was observed at $5 \%$ level of significance $(p>0.05)$.

Decreased level of serum $\operatorname{IgG} \& \operatorname{IgA}$ and increased level of serum IgM were found in dockyard labourers compared to control subjects $(p>0.05)$. In the ship breaking yards, there are poor arrangements for pure drinking water, healthy food, hygienic toilet and living place for the labourers. ${ }^{2}$ Workers in the ship breaking yards suffer from many diseases and injuries that may be due to living in unhealthy and noxious as well as risky environment round the clock. Nutritional deficiencies, such as poor nutrition or chronic energy deficiency (CED) and protein-energy malnutrition were reported to impair essentially all forms of immune function ${ }^{8}$, which may be the reason for decreased level of immunoglobulin in dockyard labourers. Again, most of the ship breaking workers come from poverty stricken regions of Bangladesh, where opportunity of employment is less. In the ship breaking yards, all the works are done manually and sometimes the workers are forced to work more than their capacity in a short time, which causes major or minor accidents very often. ${ }^{2}$ As a result, psychological stress and depression are common among dockyard labourers. It is reported that depression and anxiety alter immunoglobulin levels. Inhibition of natural killer cell activity and a decrease 
in number of lymphocytes, markers of depressed immune function, are also associated with negative emotions. ${ }^{9}$ Nutritional deficiencies are reported to impair essentially all forms of immune function which might make the labourers susceptible to infections. $^{8}$ In some studies; it was found that infectious agents may increase immunoglobulin ${ }^{10,11}$, which may clarify the higher level of IgM in dockyard labourers.

Table 1. Socio-demographic data and nutritional status of dockyard labourers $(n=100)$ and control subjects $(n=100)$

\begin{tabular}{|c|c|c|c|c|c|c|}
\hline \multirow[t]{2}{*}{ Parameter } & \multicolumn{3}{|c|}{ Dockyard labourers $(n=100)$} & \multicolumn{3}{|c|}{ Controls $(n=100)$} \\
\hline & $\mathbf{N}$ & $\%$ & Mean (SD) & $\mathbf{N}$ & $\%$ & Mean (SD) \\
\hline \multicolumn{7}{|l|}{ Education } \\
\hline Illiterate & 22 & 22 & & 34 & 34 & \\
\hline Below Secondary & 74 & 74 & & 58 & 58 & \\
\hline Secondary & 4 & 4 & & 8 & 8 & \\
\hline \multicolumn{7}{|l|}{ Occupation } \\
\hline Dock labourer & 100 & 100 & & & & \\
\hline Rickshaw Puller & & & & 38 & 38 & \\
\hline Construction Worker & & & & 62 & 62 & \\
\hline \multicolumn{7}{|l|}{ Monthly income (US\$) } \\
\hline $40-60$ & 50 & 50 & 62.63 & 66 & 66 & 58.79 \\
\hline $61-75$ & 22 & 22 & $(22.22)$ & 16 & 16 & $(19.37)$ \\
\hline $76-95$ & 16 & 16 & & 12 & 12 & \\
\hline 96-above & 12 & 12 & & 6 & 6 & \\
\hline \multicolumn{7}{|l|}{ Age in years } \\
\hline $19-24$ & 52 & 52 & 24.73 & 50 & 50 & 23.94 \\
\hline $25-30$ & 38 & 38 & $(5.21)$ & 40 & 40 & $(3.96)$ \\
\hline $31-36$ & 6 & 6 & & 8 & 8 & \\
\hline $37-42$ & 4 & 4 & & 2 & 2 & \\
\hline \multicolumn{7}{|l|}{ Marital status } \\
\hline Married & 40 & 40 & & 44 & 44 & \\
\hline Unmarried & 60 & 60 & & 56 & 56 & \\
\hline \multicolumn{7}{|l|}{ Area of residence } \\
\hline Urban & 22 & 22 & & 42 & 42 & \\
\hline Rural & 22 & 22 & & 52 & 52 & \\
\hline Semi-Urban & 56 & 56 & & 6 & 6 & \\
\hline \multicolumn{7}{|l|}{ Smoking Habit } \\
\hline Non smoker & 24 & 24 & & 34 & 34 & \\
\hline Smoker & 72 & 72 & & 64 & 64 & \\
\hline Ex Smoker & 6 & 6 & & 2 & 2 & \\
\hline \multicolumn{7}{|l|}{ BMI (Kg/m²) } \\
\hline $13.8-16.8$ & 40 & 40 & & 26 & 26 & \\
\hline 16.9-19.9 & 42 & 42 & 19.683 & 50 & 50 & 20.74 \\
\hline $20-23$ & 16 & 16 & $(2.38)$ & 18 & 18 & $(2.50)$ \\
\hline $24-27$ & 2 & 2 & & 6 & 6 & \\
\hline
\end{tabular}

Normal human BMI ranges from 18.5-25 (Food and Agriculture Organization, 1994)

Table 2. Mean serum immunoglobulin (IgG, IgA and IgM) level of dockyard labourers $(\mathrm{n}=100)$ and control subjects $(\mathrm{n}=100)$

\begin{tabular}{ccccc}
\hline Immunoglobulin & \multicolumn{3}{c}{ Mean serum concentration $(\mathrm{mg} / \mathrm{dl})$} \\
\cline { 2 - 5 } & Normal values $^{12}$ & Dockyard labourers & Control subjects & $\begin{array}{c}p \text {-value } \\
\text { (2-tailed) }\end{array}$ \\
\hline IgG & $800-1801$ & $1161.13 \pm 357.425$ & $1193.52 \pm 302.830$ & 0.452 \\
$\operatorname{IgA}$ & $113-563$ & $238.36 \pm 80.594$ & $261.28 \pm 67.120$ & 0.685 \\
IgM & $54-222$ & $156.56 \pm 52.897$ & $137.80 \pm 55.335$ & 0.554 \\
\hline
\end{tabular}

Independent Sample $t$-test: Significance $p<0.05$ 
But further large-scale prospective study is needed to investigate the immune status in relation to health problems of dockyard labourers. These findings could direct our attention towards considering compromised immunity as a part of healthcare of this group of population.

\section{REFERENCES}

1. OSHA. 2001. Ship Breaking Fact Sheet. U.S. Department of Labor: Occupational Safety and Health Administration. http://www.osha.gov Accessed 15 Apr 2010.

2. YPSA. 2005. Workers in Ship Breaking Industries: A base line survey of Chittagong (Bangladesh). Young Power in Social Action (YPSA), p. 79.

3. Gain, P. 1998. Bangladesh Environment: Facing the 21st Century. SHED (Society for Environment and Human Development), p. 340.

4. Hossain, M.M. and Islam, M.M. 2006. Ship Breaking Activities and its Impact on the Coastal Zone of Chittagong, Bangladesh: Towards Sustainable Management. Young Power in Social Action (YPSA), pp. ix +54 . http://www.ypsa.org/publications/Impact.pdf Accessed 15 Apr 2010

5. Khanam, M., Azad, M.A.K., Ullah, M.A., Ahsan, M.S., Bari, W., Islam, S.N. and Hasnat, A. 2008. Serum immunoglobulin profiles of conversion disorder patients. German Journal of Psychiatry. 11, 141-145.
6. Mannan, S.J., Azad, M.A., Ullah, M.A., Maruf, A.A., Rayhan, M.I., Ahsan, M.S. and Hasnat, A. 2010. Investigation of Serum Trace Element, Malondialdehyde and Immune Status in Drug Abuser Patients Undergoing Detoxification. Biol Trace Elem Res. Apr 14, [Epub ahead of print]

7. Ali, R., Ahsan, M.S., Azad, M.A., Ullah, M.A., Bari, W., Islam, S.N., Yeasmin, S. and Hasnat, A. 2010. Immunoglobulin levels of vitiligo patients. Pak J Pharm Sci. 23, 97-102.

8. Islam, S.N., Hossain, K.J., Kamal, M. and Ahsan, M. 2004. Serum innunoglobulins and white blood cells status of drug addicts: influence of illicit drugs and sex habit. Addict Boil. 9, 27-33.

9. Frasure, A. and Smith, N. 2000. Depression and anxiety. Circulation. 101, 1919-1924.

10. Buckley, R.H. 2000. Evaluation of the immune system. In: The immunologic system disorders (Behrman, R.E., Kliegman, R.M., Jenson, H.B., Eds.), Nelson textbook of pediatrics, $16^{\text {th }}$ edition. Thomson Press Ltd. Noida, India, pp. $588-590$.

11. Prober, C.G. 2000. In: Pneumonia (Behrman, R.E., Kliegman, R.M., Jenson, H.B., Eds.), Nelson textbook of pediatrics, $16^{\text {th }}$ edition. Thomson Press Ltd. Noida, India, pp. 761-765.

12. ASCLS. 1997. Chemistry tests/Immunoglobulin (adults). The Society for American Clinical Laboratory Science. http://www.ascls.org/labtesting/labchem.asp Accessed 15 July 2010 . 